\title{
Characteristics and experiences of etonogestrel-releasing contraceptive implant users in a cohort of Turkish women
}

\section{Türk kadın kohortunda etonogestrel salan kontraseptif implant kullanıcılarının özellikleri ve deneyimleri}

\author{
Demet Kokanali* Meryem Kuru Pekcan
}

Zekai Tahir Burak Woman's Health Education And Research Hospital, Department of Obstetrics and Gynecology, Ankara/Turkey

\begin{abstract}
Aim: To determine the characteristics and experiences of Etonogestrel-releasing implant users in Turkish women cohort.

Material and Methods: A retrospective cohort study carried out in a tertiary referral public hospital. The charts of ninetyone women who had Etonogestrel-releasing implant inserted between January 2014, and April 2016 were reviewed.

Results: Of ninety-one women, over half (52.8\%) were aged $\geq$ thirty and a few were < twenty-five (5.5\%). Only three (3.3\%) women were nulliparous. Over half were university or higher graduated (54.9\%) and employed (58.2\%). Efficacy was the most commonly cited reasons to choose the method. Overall continuation rates were $75.0 \%$ at twenty-five months and $50.0 \%$ at thirty-four months. Twenty-nine women removed implant before the period of use expired. Eighteen of these wanted to conceive and the other eleven discontinued because of side effects they experienced. Irregular menstrual bleeding was the most frequent side effect for removal. No woman conceived while using the method.
\end{abstract}

Conclusion: Etonogestrel-releasing implant is used for its efficacy by a range of Turkish women who are especially parous, well-educated and employed. While it has high continuation rates, irregular menstrual bleeding is the commonest side effect for early removal.

Keywords: contraception; etonogestrel; implant

Corresponding author*: Demet Kokanall, Zekai Tahir Burak Woman's Health Education And Research Hospital, Department of Obstetrics and Gynecology, Ankara/Turkey 


\section{Öz}

Amaç: Türk kadın kohortunda etonogestrel salan implant kullanıcılarının özelliklerini ve deneyimlerini belirlemek.

Gereç ve Yöntemler: Bu retrospektif kohort çalışma, tersiyer bir referans devlet hastanesinde gerçekleştirildi. Ocak 2014 ile Nisan 2016 arasında Etonogestrel salan implant yerleştirilmiş 91 kadının verileri gözden geçirildi.

Bulgular: Doksan bir kadının yarısından fazlası $(\% 52,8) \geq 30$ ve birkaçı $25(\% 5,5)$ yaştaydı. Sadece $3(\% 3,3)$ kadın nullipardı. Yarısından fazlası universite ve üstü okullardan mezundu $(\% 54,9)$ ve bir işte çalışmaktaydı $(\% 58,2)$. Etkinlik en fazla tercih edilme nedeniydi. Yöntemi kullanmaya devam etme oranı yirmi beş ayda \%75,0 ve otuz dört ayda \%50,0 idi. Yirmi dokuz kadın, kullanım süresi dolmadan implantı çıkardı. Bunların 18'i gebe kalmak istedi ve diğer 11'i yaşadıkları yan etkiler nedeniyle implant kullanmayı bıraktı. Düzensiz adet kanaması, en sık görülen yan etkiydi. Bu yöntemi kullanırken hiçbir kadında gebelik oluşmadı.

Sonuç: Etonogestrel salan implant, özellikle doğum yapmış, iyi eğitimli ve bir işte çalışan Türk kadını tarafından etkinliği için kullanılmaktadır. Kullanımına devam etme oranları yüksek olmasına rağmen, düzensiz adet kanaması erken çıkartma nedeni olan en sık yan etkisidir.

Anahtar kelimeler: kontrasepsiyon; etonogestrel; implant

\section{Introduction}

The etonogestrel-releasing (ENG-R) implants are progestogenonly contraceptive methods. Nexplanon (manufactured by N.V. Organon, Oss, The Netherlands) is the currently available type of this method. It is the second-generation of the device; the first generation was introduced as Implanon (manufactured by N.V. Organon, Oss, The Netherlands). Nexplanon differs from Implanon counterpart in that it has a new applicator designed to make insertion easier and prevent deeper placement. And unlike Implanon, Nexplanon itself is radiopaque (contains barium sulfate), therefore impalpable devices can be located by X-ray or computed tomography (CT) scan. On the other hand, both devices are $4 \mathrm{~cm}$-long, $2 \mathrm{~mm}$-diameter, single-rod contraceptive implants that are placed subdermally along the upper medial arm; both contain $68 \mathrm{mg}$ of the synthetic progestin etonogestrel, the biologically active metabolite of desogestrel. Initially, the release rate of this hormon in these devices is 60-70 $\mu \mathrm{g} /$ day and then slowly decreases over time to approximately $30 \mu \mathrm{g} /$ day which is enough to inhibit ovulation and provides effective contraception protection for up to 3 years [1,2].

These implants do not contain estrogen, therefore they can be prefered as a good contraceptive option among women who have contraindications for estrogen use. Additionally, they provide long-acting contraception without any dosage adjustment and they do not cause delay in return to fertility when removed. Moreover, they are highly effective with low failure rate, and are safe with rare complications (pain, hematoma, redness...etc) during insertion or removal and adverse reactions such as bleeding irregularities, emotional lability and weight increase [1-4]. Despite these features, their use is low. Worldwide, $53.0 \%$ of married women aged between 15-49 years use modern contraceptive methods, but fewer than one percent of these women use implants [5].
In developing countries such as Turkey, maternal mortality and morbidity are high. Therefore, prevention of unplanned pregnancies may prevent up to $30 \%$ of pregnancy related maternal deaths and $10 \%$ of childhood deaths [6]. However, women in the such countries who desire access to contraception face a multitude of technical and programmatic barriers, even if progress has been made over the past several decades. Moreover, despite this progress, the increase in contraceptive prevalence has not been sufficient to decrease overall unmet need in many areas [7].

In this study we aimed to examine the characteristics of ENG-R implant users among the married women living in the center of Turkey and to determine their experiences and continuation rates over a three-year period, as well as their reasons for discontinuation.

\section{Material and Methods}

After obtaining institutional review board approval (No:3, Date: 30.12 .2015 ) for this retrospective study, we reviewed the charts of women opted for and had ENG-R implant inserted after counseling at the Family Planning Department of our hospital between January 1, 2014, and April, 12016.

Data on the sociodemographic characteristics, reproductive history, medical history and insertion date were collected from hospital records. Using telephone interviews, women were asked whether the implant was still in situ and if yes, information on women's experience with side effects was collected. If the implant had been removed, women were asked for discontinuation reasons and removal date. The women who had insufficient data were only excluded.

Data were analysed using statistical packages for the social sciences (SPSS) version 17.0 for Windows (SPSS Inc, Chicago, IL, USA). We used standard descriptive statistics to describe demographics and clinical characteristics and summarized continuous variables with means and standard deviations and categorical variables by number of women and percentages. ENG-R implant continuation 
rates were calculated using a Kaplan-Meier survival curve. Since we planned to enroll all potentially eligible women for this study, a power calculation was not performed.

\section{Results}

A total of 91 women were included in this study. The demographic characteristics of these women were listed in Table 1. The mean age of the women using ENG-R implant was $30.59 \pm 5.16$ years. Over half of women (52.8\%) were $\geq 30$ years of age while $5.5 \%$ were under 25 years. Mean body mass index was $27.6 \mathrm{~kg} / \mathrm{m} 2$; $73.6 \%$ of women were overweight and $11.0 \%$ were obese. Only 3 (3.3\%) women were nulliparous. Over half of women (54.9\%) were university or higher graduates and over half (58.2\%) were employed. About $45.0 \%$ of women had future fertility desires at the time of commencing the use of ENG-R implant. More than $60.0 \%$ of women had regular menstrual cycles and reported previous use of a contraceptive method. Lastly, proportion of women that were breastfeeding at the time of accepting the ENG-R implant insertion was $9.9 \%$ in our study population.

Table 1. Demographic properties of the users at insertion of etonogestrel-releasing implant $(\mathrm{n}=91)$

Variables

Age during insertion (years)

$$
30.59 \pm 5.16
$$

20-24

$$
5 \quad(5.5)
$$

25-29

38 (41.8)

30-39

$\geq 40$

Body Mass Index $(\mathrm{kg} / \mathrm{m} 2)$

$27.6 \pm 1.9$

Normal (18.5-24.9 kg/m2)

$14 \quad(15.4)$

Overweight (25.0-29.9 kg/m2)

$67 \quad(73.6)$

Obese $(\geq 30 \mathrm{~kg} / \mathrm{m} 2)$

$10 \quad(11.0)$

Number of live births

0

3

1

26

$\geq 2$

62

Education

\begin{tabular}{l|l} 
High school or lower & 50
\end{tabular}

University or higher

41

Employement

Employed

53

Unemployed

38

Future children desire

No

50

Yes

41

Previous use of a contraceptive method

No

31

Yes

60

Breastfeeding at insertion

No

82

Yes

9

Women reported a number of reasons why they accepted to use the ENG-R implant (Table 2) with the most common reason $(44.0 \%, n=40)$ being that it is an effective method. The next most frequently identified reasons were long-acting use $(20.9 \% ; n=19)$ and need no control or follow-up requirement $(12.1 \%, n=11)$. The other reasons were shown in Table 2.

Table 2. Reasons to choose etonogestrel-releasing implant (women were able to provide only most important one) $(\mathrm{n}=91)$.

Being effective $40 \quad(44.0)$

Being long-acting 19 (20.9)

Being no control or follow-up requirement

Being recommended by clinician

$11 \quad(12.1)$

Being recommended by friends

$10 \quad(11.0)$

Being quickly reversible on removal 9

Values were presented as n (\%).

2

Of the 91 women, 7 (7.7\%) were still using the implant at one year and 13 (14.3\%) were using it at two years. And 27 (29.7\%) women had used the method for three years. Time of ENG-R implant retention was $27.40 \pm 8.07$ months. Kaplan-Meier survival curve estimating continuation rates for the method was shown in Figure 1.75.0\% of women continued to use this implant at 25 months and $50.0 \%$ at 34 months. No women conceived while using this method.

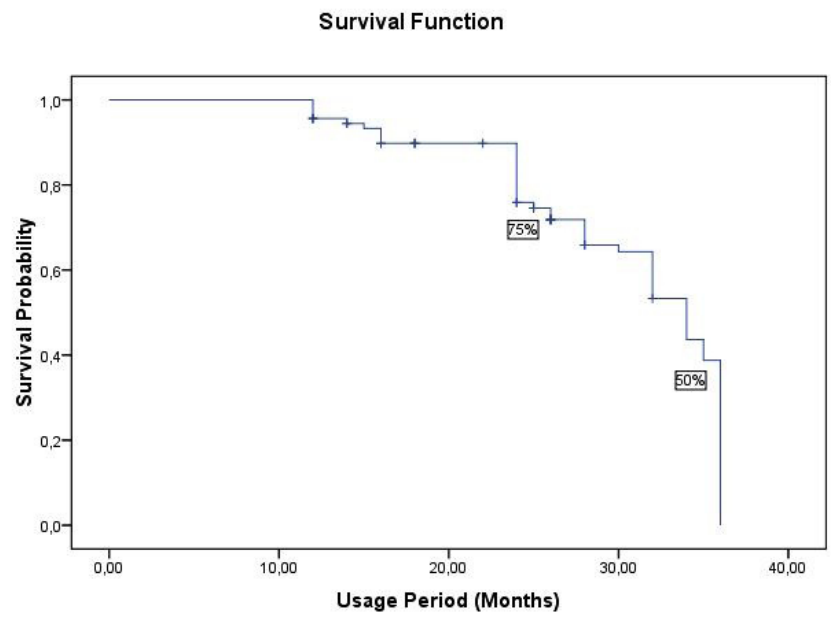

Figure 1. Kaplan-Meier survival curve estimating continuation rates for Etonogestrel-releasing implant in study group. Data show continuation rates of $75 \%$ at 25 months and $50 \%$ at 34 months. Recommended time for removal of Etonogestrel-releasing implants is 36 months.

Seventeen (18.7\%) women stated that they had some side effects including irregular menstrual bleeding, headache, weight gain, breast pain, acne and emotional lability while using implant. Twenty-nie (31.9\%) of the women removed implants before the period of use expired. 18 (19.8\%) of these wanted to conceive and the other 11 (12.1\%) women discontinued because of the side effects they experienced. 
Of the women who discontinued method due to side effects, 4 women (36.3\%) do so within the first year, 4 (36.3\%) do so within the second year and 3 (27.3\%) do so within the third year. The women who wanted to get pregnant used this method for $22.28 \pm 6.10$ months while women who discontinued implant because of side effects used it for $16.29 \pm 8.64$ months. As documented in Table 3, among the side effects that caused the removal, the most two common ones were irregular menstrual bleeding $(5 / 11,45.5 \%)$ and headache $(2 / 11,18.2 \%)$.

\begin{tabular}{|l|lc||cc|}
\hline Table 3. Primary reason for discontinuation $(\mathrm{n}=29)$ \\
\hline 1. Side effects & 11 & $(37.9)$ & 5 & $(45.5)$ \\
Irregular menstruel bleeding & & 2 & $(18.2)$ \\
Headache & & 1 & $(9.1)$ \\
Weight gain & & 1 & $(9.1)$ \\
Breast pain & & 1 & $(9.1)$ \\
Acne & & 1 & $(9.1)$ \\
Mood swings & & & \\
\hline 2. Desire to conceive & 18 & $(62.1)$ & & \\
\hline Values were presented as $\mathrm{n}(\%)$. & \multicolumn{3}{|l}{} \\
\hline
\end{tabular}

\section{Discussion}

In our study, only 5 of these women were $\leq 24$ years of age. In Turkey, almost all married women are aware of at least one family planning method. The intrauterine device, the pill, tubal sterilization, and the male condom are among the most well-known modern methods. However, probably due to insufficient family planning counseling only 39\% of married women (without any differences appearing between the age groups) are aware of the subdermal implants [8]. In our study, only $5(5.5 \%)$ of the women who used ENG-R implant were $\leq$ 24 years of age. Even though sufficient counseling is given, it is possibly that the young women do not prefer this method too much because they do not want to use the long-acting contraceptive method.

Previous studies have showed that the number of living children seems to be positively associated with women's use of implant $[9,10]$. Multiparous women may not desire more children if they are satisfied with their number of children. Therefore, they may prefer ENG-R implant and other longacting contraceptive methods. Similarly, more than half of the implant users in our study had $\geq 2$ living children, and over half of the users had no desire to have more children in the future.

The use of ENG-R implant is limited in developing countries such as Turkey, where it is not covered by health insurance. Therefore, once education level increases and economic status improves, the frequency of modern contraceptive use among women increases [9,11-13]. Naturally, women with high education levels and good economic statuses can make decisions freely, have financial autonomy, have better access to health care services or information, and are more equipped to persuade their spouses about contraception. Our study congruently indicated that ENG-R implant use was more frequent in women with higher levels of education and employment.

Among the implant users in our study, those who had used a previous contraceptive method were more common than those who had not. This may be explained by the fact that women who have previously used any contraceptive methods may be more aware of the benefits or side effects of same and other contraceptives and may have more accurate information about methods $[9,11,14,15]$. Additionally, they may prefer long-acting contraceptives instead of short-acting ones or prefer among the long-acting contraceptive methods.

In our single-center study in Turkey, the mean overall ENG-R implant continuation period was 27.40 months, which is longer than the average of about 24 months in previous studies $[3,16]$. Furthermore, the continuation rates of $75.0 \%$ after 2 years and $50.0 \%$ after nearly 3 years found in our study were greater than in the other studies [16-19]. The most significant reason women in our study chose ENG-R implant was their belief that this method was effective. Women in Turkey may believe that implants are more effective than other methods and therefore use this method longer despite the possible side effects.

In our study, women discontinued ENG-R implant for two reasons: the desire to conceive and the experience of side effects. Side effects were experienced by $18.7 \%$ of women using the method. Among the side effects that caused implant removal, the most common was irregular bleeding. Other causes included headaches, weight gain, breast tenderness, acne, and emotional instability. These findings are consistent with the literature. The incidence of the side effects listed above can be observed as high as $20 \%$ or as low as $1 \%$ in women using $[3,20]$. An irregular bleeding pattern is the most frequently observed side effect and is the most common cause of early removal of ENG-R implant [16,18,21-23]. In previous studies, irregular bleeding as the main reason to remove the implant early varies from $10 \%$ to $40 \%$ [20,22-24]. In our study, this percentage was $17.2 \%$. Additionally, nearly one-third of the women who discontinue ENG-R implant use due to side effects does so during the first year, and almost another third does so during the second year, similar to previous studies $[16,25]$. In our study, the women who discontinued implant 
use due to side effects used the method for a shorter period than those who discontinued use due to desire to conceive. This continuation period was 16.3 months, which is consistent with the findings of other studies [15-18,21,22,26].

Our study has some limitations. This was a retrospective study that relied on data collected from hospital records. Some of these data may have been missing or inaccurate, which may have altered the results of the study. Moreover, our data were from a single family-planning clinic in Turkey and included a small number of nulliparous and adolescent women. Therefore, our study cannot be generalized to the Turkish population or nulliparous and adolescent women. However, the results of this study have improved our understanding of the profile of women who choose ENG-R implant as well as the reasons for its discontinuation. This information will be useful for developing further strategies to deliver this method to the underserved members of the community.

\section{Conclusion}

ENG-R implant is used by a range of Turkish women who are especially parous, well-educated, and employed. This may be an indicator for the characteristics of ENG-R implant users in developing countries. While an irregular bleeding pattern is the main reason for early discontinuation, the overall continuation rate is high. Therefore, pre-insertion counselling should emphasize potential changes in bleeding patterns. Furthermore, to ensure that the use of this effective, longacting contraceptive method is widespread in developing communities such as Turkish society, it is important for health professionals to develop community-based strategies for health policies, to know the necessary medical interventions against side effects, especially abnormal bleeding, and to be aware of the experiences of ENG-R implant users.

\section{Declaration of conflict of interest}

The authors received no financial support for the research and/or authorship of this article. There is no conflict of interest.

\section{References:}

1. American College of Obstetricians and Gynecologists. ACOG Practice Bulletin No. 186 Summary: Long-acting reversible contraception: implants and intrauterine devices. Obstet Gynecol 2017; 130: 1173-75.

2. Palomba S, Falbo A, Di Cello A, Materazzo C, Zullo F. Nexplanon: the new implant for long-term contraception. A comprehensive descriptive review. Gynecol Endocrinol 2012; 28: 710-21.

3. Darney P, Patel A, Rosen K, Shapiro LS, Kaunitz AM. Safety and efficacy of a single-rod etonogestrel implant (Implanon): Results from 11 international clinical trials. Fertil Steril 2009; 91: 1646-53.
4. Beerthuizen R. Safety and efficacy of the subdermal etonogestrel contraceptive implant Implanon. J Fam Plann Reprod Health Care 2017; 43: 118.

5. Kabir A, Bidia F, Beth F, et al. Contraceptive commodities for women's health. Hormonal implants: repared for the United Nations Commission on Life-Saving Commodities for Women and Children. 2012 March.

6. Collumbien M, Gerressu M, Cleland J. Non-use and use of ineffective methods of contraception. In: Ezzati M, Lopez $A D$, Rodgers A, Murray CJL, (eds). Comparative quantification of health risks: the global and regional burden of disease attributable to selected major risk factors. Geneva: World Health Organization; 2004:1255-319

7. Schivone GB, Blumenthal PD. Contraception in the developing world: special considerations. Semin Reprod Med 2016; 34: 168-74.

8. Türkiye Nüfus ve Sağlık araştırması 2013. Available from: http:// www.hips.hacettepe.edu.tr/tnsa2013/rapor/TNSA_2013_ana_ rapor.pdf. Accessed in 2018 (May 25).

9. Gebre-Egziabher D, Medhanyie AA, Alemayehu M, Tesfay FH. Prevalence and predictors of implanon utilization among women of reproductive age group in Tigray Region, Northern Ethiopia. Reprod Health 2017; 14: 62.

10. Cea Soriano L, Wallander M-A, Andersson S, Filonenko A, García Rodríguez LA. Use of long-acting reversible contraceptives in the UK from 2004 to 2010: analysis using the health improvement network database. Eur J Contracept Reprod Health Care 2014; 19: 439-47.

11. Steinauer JE, Upadhyay UD, Sokoloff A, et al. Choice of the levonorgestrel intrauterine device, etonogestrel implant or depot medroxyprogesterone acetate for contraception after aspiration abortion. Contraception. 2015; 92: 553-9.

12. Palamuleni ME. Socio-economic and demographic factors affecting contraceptive use in Malawi. Afr J Reprod Health. 2013; 17: 91-104.

13. Bateson D, Harvey C, Trinh L, Stewart M, Black KI. User characteristics, experiences and continuation rates of copper intrauterine device use in a cohort of Australian women. Aust N Z J Obstet Gynaecol 2016; 56 :655-61.

14. Pam VC, Mutihir JT, Nyango DD, et al. Sociodemographic profiles and use-dynamics of Jadelle (levonorgestrel) implants in Jos, Nigeria. Niger Med J 2016; 57: 314-19.

15. Takele A, Degu G, Yitayal M. Demand for long acting and permanent methods of contraceptives and factors for non-use among married women of Goba Town, Bale Zone, South East Ethiopia. Reprod Health 2012; 9: 26. 
16. Teunissen AM, Grimm B, Roumen FJ. Continuation rates of the subdermal contraceptive Implanon $\left({ }^{\oplus}\right)$ and associated influencing factors. Eur J Contracept Reprod Health Care 2014; 19: 15-21.

17. Law A, Liao L, Lin J, Yaldo A, Lynen R. Twelve-month discontinuation rates of levonorgestrel intrauterine system 13.5 $\mathrm{mg}$ and subdermal etonogestrel implant in women aged 18-44: a retrospective claims database analysis. Contraception 201821 7824: 30142-2. [Epub ahead of print]

18. Harvey C, Seib C, Lucke J. Continuation rates and reasons for removal among Implanon users accessing two family planning clinics in Queensland, Australia. Contraception 2009; 80: 527-32.

19. National Collaborating Centre for Women's and Children's Health. Long-acting reversible contraception: the effective and appropriate use of long-acting reversible contraception. London: RCOG Press; 2005. Commissioned by the National Institute for Health and Clinical Excellence.

20. Blumenthal PD, Gemzell-Danielsson K, Marintcheva-Petrova M. Tolerability and clinical safety of Implanon. Eur J Contracept Reprod Health Care 2008;13: 29-36.
21. Jeffreys LA, Clark AL. A successful approach to long-acting contraceptive implants in primary care. Contraception 2012; 85: 381-83.

22. Casey PM, Long ME, Marnach ML, Bury JE. Bleeding related to etonogestrel subdermal implant in a US population. Contraception 2011; 83: 426-30

23. Mommers E, Blum GF, Gent TG, et al. Nexplanon, a radiopaque etonogestrel implant in combination with a next-generation applicator: 3-year results of a noncomparative multicenter trial. Am J Obstet Gynecol 2012; 207: 388.

24. Ezegwui HU, Ikeako LC, Ishiekwene Cl, Oguanua TC. The discontinuation rate and reasons for discontinuation of Implanon at the family planning clinic of University of Nigeria Teaching Hospital (UNTH) Enugu, Nigeria. Niger J Med 2011; 20: 448-50.

25. Weisberg E, Fraser I. Australian women's experience with Implanon. Aust Fam Physician 2005; 34: 694-96.

26. Rubenstein J, Rubenstein P, Barter J, Pittrof R. Counselling styles and their effect on subdermal contraceptive implant continuation rates. Eur J Contracept Reprod Health Care. 2011; 16: 225-28. 